УДК 34

DOI $10.21661 / \mathrm{r}-554486$

Д.Ф. Хасанова, А.С. Болодис, А.Р. Аминева, Д.Р. Латыпова

\title{
КОЛЛИЗИОННЫЕ НОРМЫ В МЕЖДУНАРОДНОМ ЧАСТНОМ ПРАВЕ
}

Аннотация: в статье анализируется содержание, понятия и виды коллизионных норм, также рассматривается роль коллизионных норм в регулировании международных частноправовых отношений. Обосновывается, что происходит развитие международного частного права.

Ключевые слова: коллизионная норма, международное частное право, частноправовые отночения.

Коллизионные нормы исторически составляли основу международного частного права (далее - МЧП) и являются центральным институтом этой отрасти права до сих пор. Говоря о праве, вспомним цитату М.М. Богуславского: «Международное частное право - это самая непонятная юридическая дисциплина». В своем учебнике автор рассказывает о появлении в России в 1916 году научнопопулярной брошюры С.В. Рождественского «Два этюда», в которой одновременно присутствовали всего два необычных сюжета: устройство человеческого глаза и сущность МЧП.

Коллизионная норма имеет свою особенную структуру, она состоит из объема и привязки. В объеме коллизионной нормы содержится указание на общественное отношение, на регулирование которого претендуют правопорядки двух или более государств. В привязке указывается право, регулирующее данное отношение, либо закрепляется способ его определения. Иными словами, объем нормы как бы «задает направление проблемы», а привязка - находит ответ на поставленную ранее проблему. Коллизионные нормы являются нормами публичного права, они устанавливают обязанность государственных органов применять определенное право. Так, Б. Ауди говорит о наличии у коллизионной нормы двух функций:

1. Отнесение спорной ситуации к определенному правопорядку. 
2. Регулирование частных интересов.

С толкованием и применением коллизионных норм связан ряд весьма спорных вопросов, носящих крайне важный характер. Речь идет о выяснении содержания правовых категорий, содержащихся в объеме и привязке коллизионной нормы, так как одинаково сформулированные в коллизионных нормах понятия в разных государствах могут пониматься по-разному. Квалификацию и выбор применяемого права принято называть «первичной квалификацией», стадию применения избранного права «вторичной квалификацией».

Виды коллизионных норм осуществлены по различным основаниям. Некоторые из них аналогичны основаниям, используемым при классификации правовых норм как таковых. Например, по способу правового коллизионных норм может быть регулирования: императивные диспозитивные и альтернативные. К этой же группе можно отнести такое основание, как правовая природа или источник закрепления коллизионных норм: национальные, т.е. созданные и закрепленные во внутреннем праве и международные, т.е. содержащиеся в международных договорах такие нормы единообразные иногда называют (унифицированные) коллизионные нормы.

Однако большинство оснований классификации коллизионных норм характерны только для международного частного права. Объясняется это во многом своеобразием структуры и назначением коллизионных норм. Выделают такие характерные только коллизионным нормам классификации:

1. По форме коллизионной привязки:

- односторонние;

- двусторонние.

2. По четкости формулирования привязки:

- жесткие;

- гибкие.

3. По углублению нормативной конкретизации:

- генеральные (основные);

- субсидиарные (дополнительные). 
Ряд авторов предлагают также разграничивать коллизионные нормы на международные коллизионные нормы, т.е. нормы, призванные разрешать столкновение между двумя или несколькими национальными правовыми системами и межобластные (межштатные), предназначенные разрешать субъектов федеративного государства. «Для России как федеративного - государства, - отмечает М.М. Богуславский, решения так которыми законодательства применения РФ понимается определение субъектов Позволю не различных имеет существенное значение» - согласиться уважаемым Марком Моисеевичем, ибо в соответствии пунктами «о» и «п» статьи 71 Конституции РФ гражданское федеральное законодательство и коллизионное право относится к ведению Российской Федерации, что означает отсутствие у собственное правовое регулирование в данных сферах. Теоретически такая возможность существует у них в таких отраслях права как трудовое, семейное, земельное (пункт «к» ст. 72 Конституции РФ), но лишь до тех пор, пока отсутствует соответствующий у субъектов РФ возможности осуществлять федеральный закон. Учитывая, что региональное законодательство по вопросам, перечисленным статье 72 Конституции РФ, должно соответствовать межобластных в федеральному, возможности появления коллизий в Российской Федерации крайне незначительны. На наш взгляд, данная проблема более актуальна для тех федераций, где правовое регулирование гражданскоправовых отношений, включая семейно-брачных и трудовых, отнесено к компетенции субъектов Федерации (США, Канада, Индия и ряд других). В перечень таких стран, несомненно, государство - Соединенное Королевство Англии, Шотландии, Уэльса Северной Ирландии, в котором исторически каждая из частей королевства имеет собственное право в данной сфере и, как отмечалось выше, с середины 90-х годов прошлого столетия начался можно отнести юридически унитарное и после увеличения их законодательных прав достаточно активный процесс формирования собственной правовой базы. Завершая разговор о данной классификации необходимо коллизионных норм, отметить, что законодательстве практически всех стран сформулировано единое по сути правило разрешения подобных коллизий: «в случаях, когда положения настоящего Закона 
отсылают к праву страны, в которой действуют несколько правовых систем, территориальных или персональных, применимое право установленными правом этой страны» определяется в соответствии критериями.

В настоящее время кодификация международного частного права выступает главным способом систематизации и законодательного воплощения комплекса коллизионных, материально-правовых и процессуальных положений, предназначенных для регулирования частных правоотношений с иностранным элементом. При этом коллизионные нормы составляют центральную часть законодательства по вопросам международного частного права, а под материально«правовыми» вопросами имеются в виду, в первую очередь, не предписания, которые непосредственно регулируют отношения сторон, а именно материальные условия применения коллизионных норм.

\section{Список литературы}

1. Конституция Российской Федерации от 12 декабря 1993 г. (в ред. от 07.01.2020 №11-ФК3) // Российская газета. - 25.12.1993. - №197 // Собрание законодательства РФ. - 07.01.2020. - №31. - Ст. 4398.

2. Гражданский кодекс Российской Федерации (часть первая) от 30.11.1994 №51-Ф3 // Собрание законодательства Российской Федерации. - 1994. - №32. CT. 3311.

3. Богуславский М.М. Международное частное право: учебник. - 4-е изд., перераб. и доп. / М.М. Богуславский. - М.: Юристь, 2002. - 462 с.

4. Мажорина М.В. Институт правовой квалификации в международном частном праве: современный взгляд и перспективы / М.В. Мажорина // Юридическая наука и практика. - 2016. - Т. 12, №1. - С. 98-100.

Хасанова Диана Филюсовна - студент юридического факультета Стерлитамакского филиала ФГБОУ ВО «Башкирский государственный университет».

Болодис Анастасия Сергеевна - студент юридического факультета Стерлитамакского филиала ФГБОУ ВО «Башкирский государственный университет». 
Аминева Айсылу Раисовна - студент юридического факультета Стерлитамакского филиала ФГБОУ ВО «Башкирский государственный университет».

Латыпова Динара Ринатовна - студент юридического факультета Стерлитамакского филиала ФГБОУ ВО «Башкирский государственный университет». 